\title{
Structure of the Dead Sea Pull-Apart Basin From Gravity Analyses
}

\author{
U. S. Ten Brink, ${ }^{1}$ Z. Ben-Avraham, ${ }^{2}$ R. E. Bell,${ }^{3}$ M. Hassouneh,${ }^{4}$ D. F. Coleman, ${ }^{1}$ \\ G. ANDREASEN, ${ }^{5,6}$ G. TIBOR, ${ }^{2}$ AND B. COAKLEY ${ }^{2}$
}

\begin{abstract}
Analyses and modeling of gravity data in the Dead Sea pull-apart basin reveal the geometry of the basin and constrain models for its evolution. The basin is located within a valley which defines the Dead Sea transform plate boundary between Africa and Arabia. Three hundred kilometers of continuous marine gravity data, collected in a lake occupying the northern part of the basin, were integrated with land gravity data from Israel and Jordan to provide coverage to $30 \mathrm{~km}$ either side of the basin. Free-air and variable-density Bouguer anomaly maps, a horizontal first derivative map of the Bouguer anomaly, and gravity models of profiles across and along the basin were used with existing geological and geophysical information to infer the structure of the basin. The basin is a long (132 km), narrow $(7-10 \mathrm{~km})$, and deep $(\leq 10 \mathrm{~km})$ full graben which is bounded by subvertical faults along its long sides. The Bouguer anomaly along the axis of the basin decreases gradually from both the northern and southern ends, suggesting that the basin sags toward the center and is not bounded by faults at its narrow ends. The surface expression of the basin is wider at its center $(\leq 16 \mathrm{~km})$ and covers the entire width of the transform valley due to the presence of shallower blocks that dip toward the basin. These blocks are interpreted to represent the widening of the basin by a passive collapse of the valley floor as the full graben deepened. The collapse was probably facilitated by movement along the normal faults that bound the transform valley. We present a model in which the geometry of the Dead Sea basin (i.e., full graben with relative along-axis symmetry) may be controlled by stretching of the entire (brittle and ductile) crust along its long axis. There is no evidence for the participation of the upper mantle in the deformation of the basin, and the Moho is not significantly elevated. The basin is probably close to being isostatically uncompensated, and thermal effects related to stretching are expected to be minimal. The amount of crustal stretching calculated from this model is $21 \mathrm{~km}$ and the stretching factor is 1.19 . If the rate of crustal stretching is similar to the rate of relative plate motion $(6 \mathrm{~mm} / \mathrm{yr})$, the basin should be $\sim 3.5 \mathrm{~m} . \mathrm{y}$. old, in accord with geological evidence.
\end{abstract}

\section{INTRODUCTION}

Fault-bounded basins often accompany strike-slip motion in a variety of tectonic settings both in the oceans and on the continents [Christie-Blick and Biddle, 1985]. These basins, referred to as strike-slip basins, pull-apart basins, or rhomb-shaped grabens, vary in their internal structure owing to the complex stress field [Withjack and Jamison, 1986] and heterogeneous crustal rheology around strike-slip faults. Strike-slip basins are generally short-lived [Crowell, 1974] because slight reorganization of relative plate motions will change the local stress field around the basin. The evolution of shallow basins can be numerically simulated by the interaction of fracture tips or by displacement discontinuities across en echelon faults in a brittleelastic medium [Rodgers, 1980; Segall and Pollard, 1980; Bilham and King, 1989]. The evolution of deep basins (deeper than 2-3 km) is expected to be more complicated as they result from either larger displacements along the fault system or from rotation of the axis of extension relative to the fault system. Furthermore, the deformation of deep

\footnotetext{
${ }^{1}$ U.S. Geological Survey, Woods Hole, Massachusetts.

${ }^{2}$ Department of Geophysics and Planetary Sciences, Tel Aviv University, Tel Aviv, Israel.

${ }^{3}$ Lamont-Doherty Earth Observatory, Palisades, New York.

${ }^{4}$ Natural Resources Authority, Amman, Jordan.

${ }^{5}$ U.S. Geological Survey, Reston, Virginia.

${ }^{6}$ Deceased November 24, 1992.
}

Copyright 1993 by the American Geophysical Union.

Paper number 93JB02025.

0148-0227/93/93JB-02025\$05.00 strike-slip basins can either be thin-skinned (brittle upper crust above a detachment surface [Royden, 1985]) or thickskinned involving the ductile lower crust [Christie-Blick and Biddle, 1985].

The Dead Sea basin is one of the better examples of deep continental strike-slip basins. It is up to $10 \mathrm{~km}$ deep, currently subsiding, and structurally simple relative to basins in convergent plate boundaries. The basin occupies a section of the valley that extends along the transform plate boundary between Africa and Arabia (Figure 1). Despite the slow relative plate velocity $(30 \mathrm{~km}$ in the last $5 \mathrm{~m}$.y. or on average $6 \mathrm{~mm} / \mathrm{yr}$ [Joffe and Garfunkel, 1987]) it is one of the largest continental strike-slip basins $(132 \times 16 \mathrm{~km})$. Starting with Quennell [1959], several models were suggested for the evolution of the basin [Freund and Garfunkel, 1976; Zak and Freund, 1981; Schubert and Garfunkel, 1984; Arbenz, 1984; ten Brink and Ben-Avraham, 1989]. These models were poorly constrained due to the limited subsurface data.

In $1988,300 \mathrm{~km}$ of marine gravity data were collected in the submerged part of the Dead Sea basin (named the Dead Sea) from a small utility vessel using the Bell Aerospace BGM-3 marine gravity system (Plate 1). To the best of our knowledge, this was the first time that continuous gravity measurements were carried out in a lake with a modern marine gravimeter. The thawing of the political climate in the Middle East allowed us also for the first time to integrate the land gravity data from Israel and Jordan, the two countries that divide the basin. Thus we are able to present here a complete gravity map of the Dead Sea basin, to use the gravity field to interpret the internal structure of the basin, and to propose a conceptual model for its evolution. More detailed gravity maps are also being published by ten Brink et al. [1993]. 


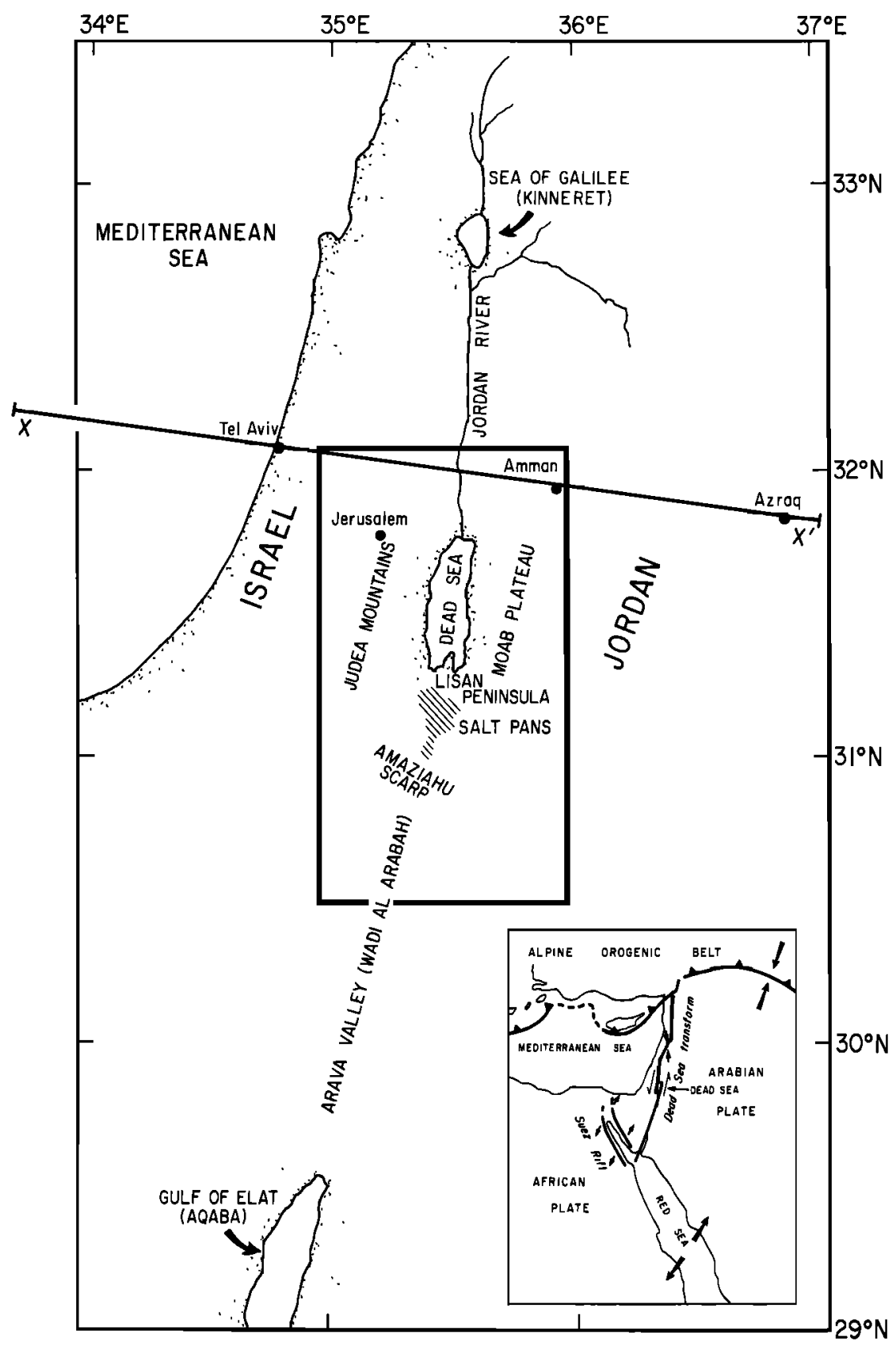

Fig. 1. Location map of the Dead Sea basin. Heavy rectangle indicates location of topography, gravity, and structural maps (Plates 1-4 and Figure 7). Heavy line $X-X^{\prime}$ is location of Figure 3. Inset shows configuration of tectonic plates.

\section{Regional Geologic Setting}

The crust underlying the study area was assembled during the Pan-African orogenies in the Late Precambrian [Freund and Garfunkel, 1976]. The thinning of the crust and the thickening of the sedimentary cover northward and westward toward the Mediterranean Sea represent a passive continental margin of the Arabo-Nubian platform resulting from a Triassic to Early Jurassic rifting [e.g., Ginzburg and Folkman, 1981]. Wide-spread deposition of marine sediments on the thermally subsiding continental margin continued until the middle Eocene and constitutes a large part of the overall sedimentary sequence [Freund and Garfunkel, 1976]. Minor NW-SE directed compression during the Late Cretaceous and early Cenozoic reactivated some older nor- mal faults and created a fold belt known as the Syrian Arc. A hiatus in deposition, most likely caused by falling sea level, occurred during the late Oligocene to Miocene [Freund and Garfunkel, 1976]. Continental and fluvial deposits of the Hazeva Formation of Miocene age, unconformably overlying the Eocene to Senonian section, are found in the

Plate 1. (Opposite) Simplified topographic map of the Dead Sea basin and its vicinity and locations of gravity stations (dots on land and lines in the lake). Dark blue, lake; light blue, salt pans; green, Quaternary rock cover within the transform valley; yellow, Miocene Hazeva Formation within the transform valley [after Picard and Golani, 1965; Bentor et al., 1965]. Colored area generally coincides with the transform valley. 


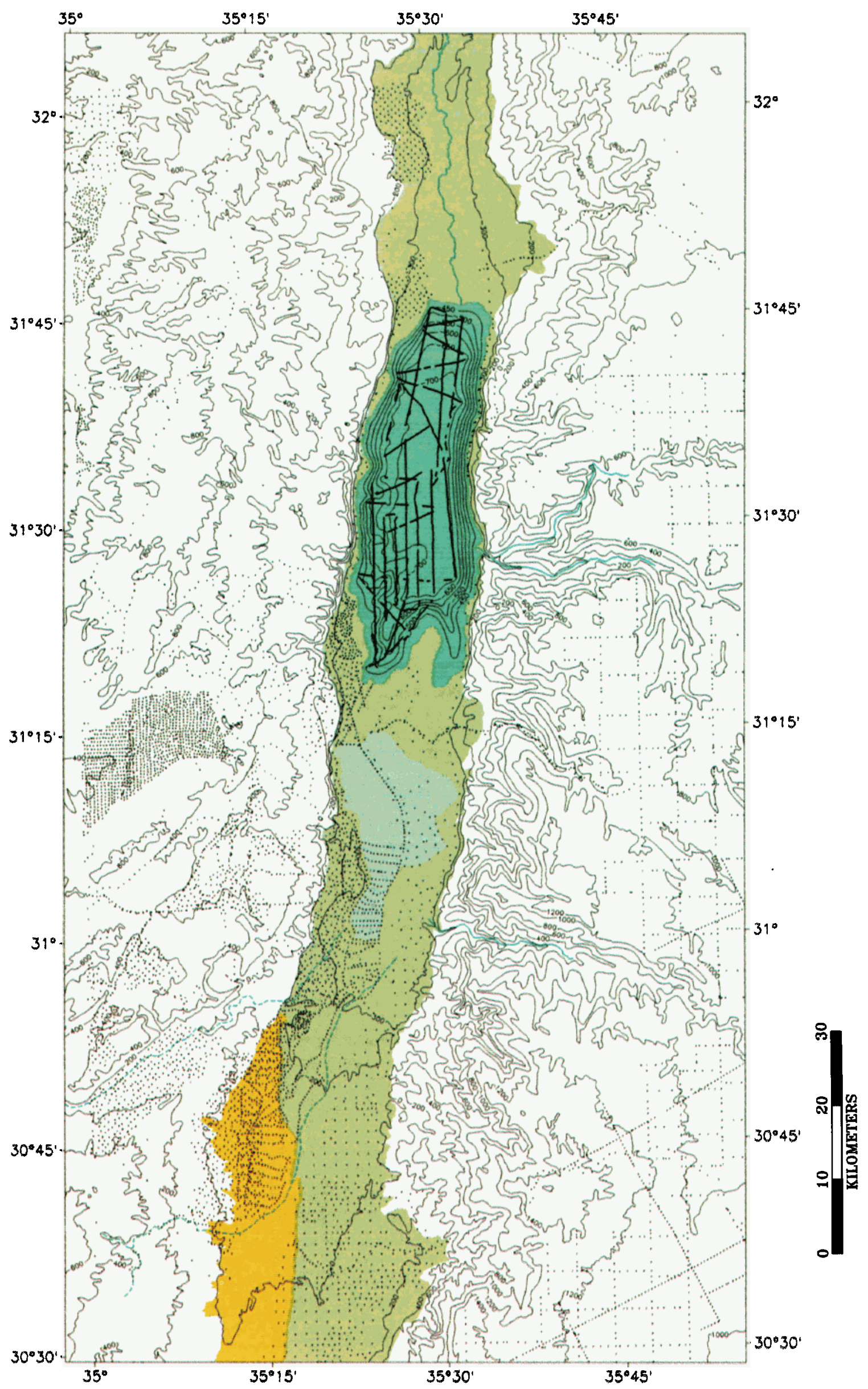


Dead Sea area both in and outside the transform valley [Kashai, 1989]. Motion along the Dead Sea transform probably initiated in the middle Miocene (15.5-11.5 Ma), but the exact age cannot be established [Steckler and ten Brink, 1986]. The initial movements along the Dead Sea transform were nearly pure strike-slip, but in post-Miocene time they may have changed to strike slip with a small component of oblique extension resulting in the opening of basins along the transform valley and the Gulf of Elat (Aqaba) [Garfunkel, 1981]. Of the $105 \mathrm{~km}$ of total left-lateral offset along the transform, only $30 \mathrm{~km}$ probably occurred in the last $5 \mathrm{~m} . \mathrm{y}$., implying a slow average relative plate velocity $(6 \mathrm{~mm} / \mathrm{yr})$ between Arabia and Africa [Joffe and Garfunkel, 1987]. Subsidence of the Dead Sea basin probably commenced in the Pliocene with the deposition of the mostly evaporitic Sedom Formation and accelerated during the Pleistocene with the deposition of several kilometers of lacustrine, fluvial, and continental sediments. Remnant pockets of Pliocene marine sediments and the composition of Pleistocene conglomerates within the basin indicate that significant flank uplift and erosion started only during the Pleistocene [Sa'ar, 1985; ten Brink and Ben-Avraham, 1989; Ilani, 1990].

\section{Data Acquisition, Reduction, and Compilation}

In October 1988 the Lamont-Doherty Earth Observatory's marine gravimeter BGM-3 was installed on the 15-m-long utility boat Tiulit in the Dead Sea. This system has a documented accuracy of better than $1 \mathrm{mGal}$ [Bell and Watts, 1986]. Gravity was continuously measured during 3 days and 1 night at an average speed of 5 knots. Gravity was recorded at a 1-s interval and monitored in the field using two COMPAQ 386 computers. Navigation was measured every 1 $\mathrm{s}$ by a portable radar-ranging system (Mini-Ranger) of the Israel National Oceanographic and Limnological Institute using three stations located at intervals of $10-15 \mathrm{~km}$ on the western shore of the lake. The positional accuracy of the system was $3 \mathrm{~m}$. A visual steering program allowed accurate control of the boat's course and speed. Water depth was measured using an analog $3.5 \mathrm{kHz}$ DFS-6000 echo sounder of the Israel National Oceanographic and Limnological Institute with an accuracy of $0.5 \mathrm{~m}$ (in seawater). The elevated salt concentration of Dead Sea water affects both the water density and its acoustic velocity. Four calibrations of the recorded travel time to the lake bottom, made by sounding with a weighted line, gave a water velocity of 1755 $\mathrm{m} / \mathrm{s}$ which is within $1 \%$ of the previous calibration [Hall and Neev, 1975]. Additional bathymetry was digitized from single-channel seismic profiles [Neev and Hall, 1976] and integrated with our data. The lake level during data acquisition (October 10-13, 1988) was $408.13 \mathrm{~m}$ below the Mediterranean sea level (bsl).

A moving average filter with a 200 -s Gaussian window was applied to the marine gravity data to remove the accelerations of the boat. The data were manually edited to remove bad measurements and were combined with the navigation. The drift of the gravity meter was negligible over the short period of the survey. Eötvös correction was applied to compensate for the ship's speed. The accuracy of the gravity measurements, after adjusting for internal consistency between crossing lines, is $1.5 \mathrm{mGal}$ [Wessel and Watts, 1988]. The marine gravity measurements were tied to a land gravity station, established by the Institute of Petroleum Research and Geophysics (Israel), at the pumping station of the Dead Sea Works Company on the southwestern shore of the lake. This station was, in turn, tied to two regional stations of the Israeli gravity network.

Observed gravity values for land stations in Israel (Plate 1), obtained from the archives of the Institute of Petroleum Research and Geophysics, Israel, were recalculated using the 1967 International Gravity Formula to match the marine data and the data from Jordan. Original field readings of land stations in Jordan (Plate 1), obtained from the archives of the Natural Resources Authority, Jordan, were converted to gravity values, corrected for gravimeter drift, and edited (L. North et al., written communication, 1992). The Jordanian data set also included gravity values from land stations collected and edited by Amoco Oil Company. Terrain correction was not applied to any of the data sets.

Merging the marine and the Israeli data with the Jordanian data presented the largest uncertainty in the accuracy of the gravity data set since a reliable tie has never been established between the gravity networks of the two countries. A large difference was present between the gravity values of the two countries, whose likely source is the $12-16 \mathrm{mGal}$ error in the absolute Potsdam gravity value [Morelli, 1971]. The Potsdam value was the base station for the global gravity network preceding the International Gravity Standardization Net (IGSN) 1971. The Israeli network is probably tied to the Potsdam network, whereas the Jordanian network is tied to IGSN 1971. To find the exact difference, we compared gravity points measured at close geographical proximity across the international border (Figure 2). A difference of $15.5-17.0 \mathrm{mGal}$ was calculated among five pairs of gravity points located along the dikes surrounding the Israeli and Jordanian salt pans between latitudes $31^{\circ} 7.5^{\prime} \mathrm{N}$ and $31^{\circ} 10.2^{\prime} \mathrm{N}$. These points are only $450-650 \mathrm{~m}$ apart, and their elevations are well known. Gravity gradients were also calculated along two short east-west profiles on the Israeli dikes at latitudes $31^{\circ} 5.3^{\prime} \mathrm{N}$ and $31^{\circ} 6^{\prime} \mathrm{N}$, extrapolated eastward, and compared to two Jordanian gravity points with differences of 14.2 and $15.2 \mathrm{mGal}$. The median value of all the above comparisons, $15.5 \mathrm{mGal}$, was subtracted from the Israeli and marine data before merging the data sets. Figure 2 demonstrates that after applying this offset, the gravity contours are continuous across the international border.

\section{TOPOGRAPHY AND FREE-AIR GRAVITY}

The morphology of the Dead Sea transform resembles many continental rift zones and oceanic fracture zones and consists of a $\sim 20-\mathrm{km}$-wide median valley and uplifted flanks [ten Brink et al., 1990]. The presence of the pull-apart basin within the valley does not appear to affect the width of the valley or the elevation of the flanking highlands. The highlands east of the basin (Moab Plateau) have an asymmetric topographic profile, a 1400-m-high escarpment facing the basin and a gentle slope away from it (Plate 1). There are only few identifiable traces of normal faults along the eastern escarpment [Picard and Golani, 1965; Bentor et al., 1965; Bender, 1968]. A wall-like escarpment, up to $300 \mathrm{~m}$ high, along the western edge of the basin (north of $30^{\circ} 55^{\prime} \mathrm{N}$ ), is the surface expression of a normal fault trace [Picard and Golani, 1965; Bentor et al., 1965]. Westward from the western escarpment, the topography rises across the 


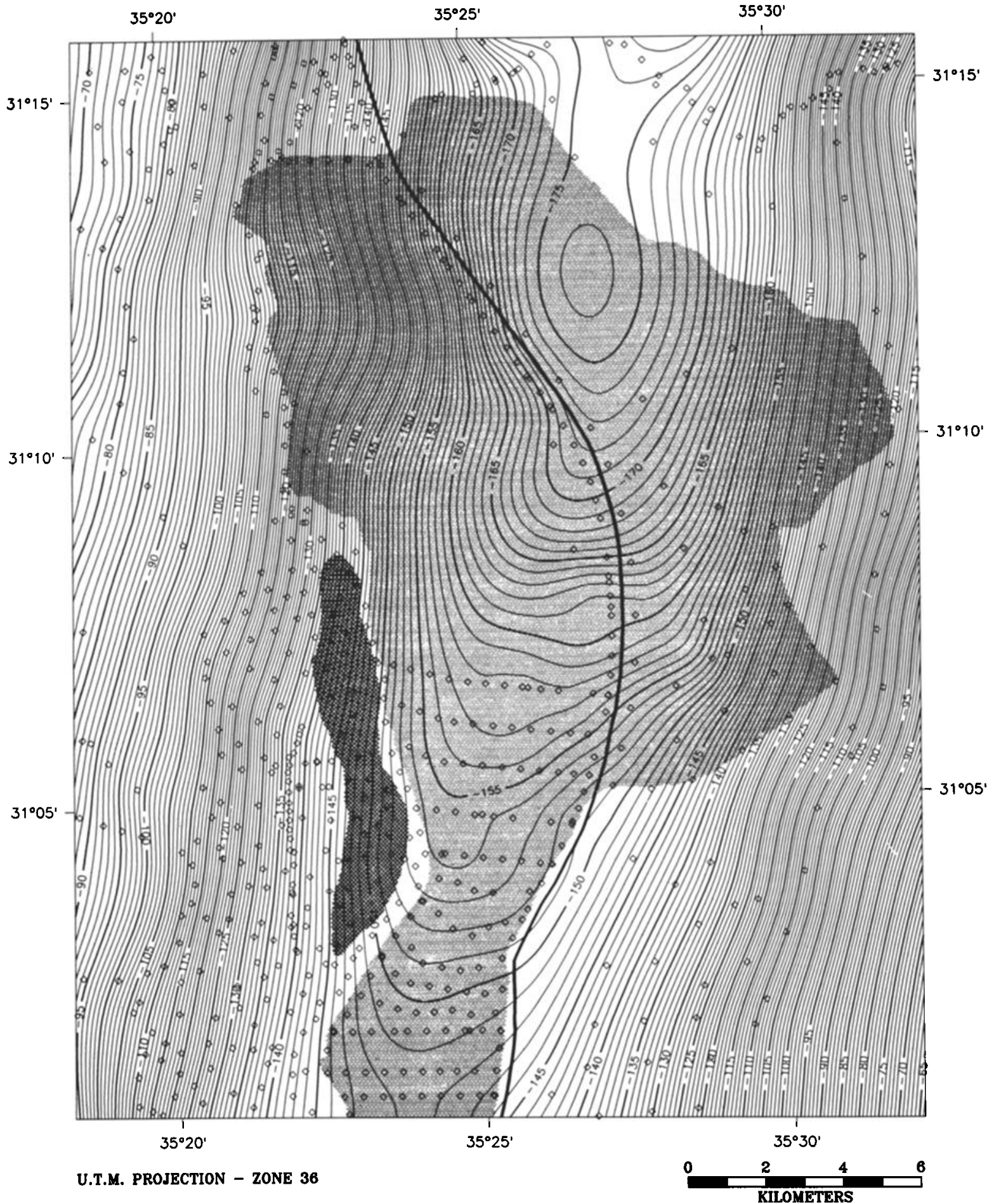

Fig. 2. Bouguer anomaly map of the salt pans (light shading) and Mount Sedom salt diapir (dark shading). Mount Sedom is a salt diapir with an exposed roof [Zak, 1967], a surface area of $10 \times 1.5 \mathrm{~km}$, and a depth of $3-4 \mathrm{~km}$ [ten Brink and Ben-Avraham, 1989, Figure 7]. Contour interval is $1 \mathrm{mGal}$. Open symbols are location of gravity stations. Heavy line is international border between Israel and Jordan. The Bouguer anomaly was calculated using a density of 2150 $\mathrm{kg} / \mathrm{m}^{3}$, referenced to a depth of $408.13 \mathrm{~m}$ below sea level, and gridded at $250 \mathrm{~m}$ square cell size. Note the absence of a gravity anomaly over this large diapir, suggesting that the density of the diapir is similar to that of the surrounding sediments that fill the basin. Gravity stations on both sides of the border between latitudes $31^{\circ} 05^{\prime} \mathrm{N}$ and $31^{\circ} 10^{\prime} \mathrm{N}$ were used to determine the differences between the Israeli and Jordanian gravity networks.

NE-SW trending Syrian Arc monoclines to the axis of the Judea Mountains.

The condition of isostasy (hydrostatic equilibrium) predicts that long wavelength free-air gravity anomalies over mountain ranges will be near zero. The large positive free-air gravity anomalies over the highlands and the large negative anomaly over the basin (Plate 2 and Figure 3 ) suggest that the topography is not isostatically compensated at these 


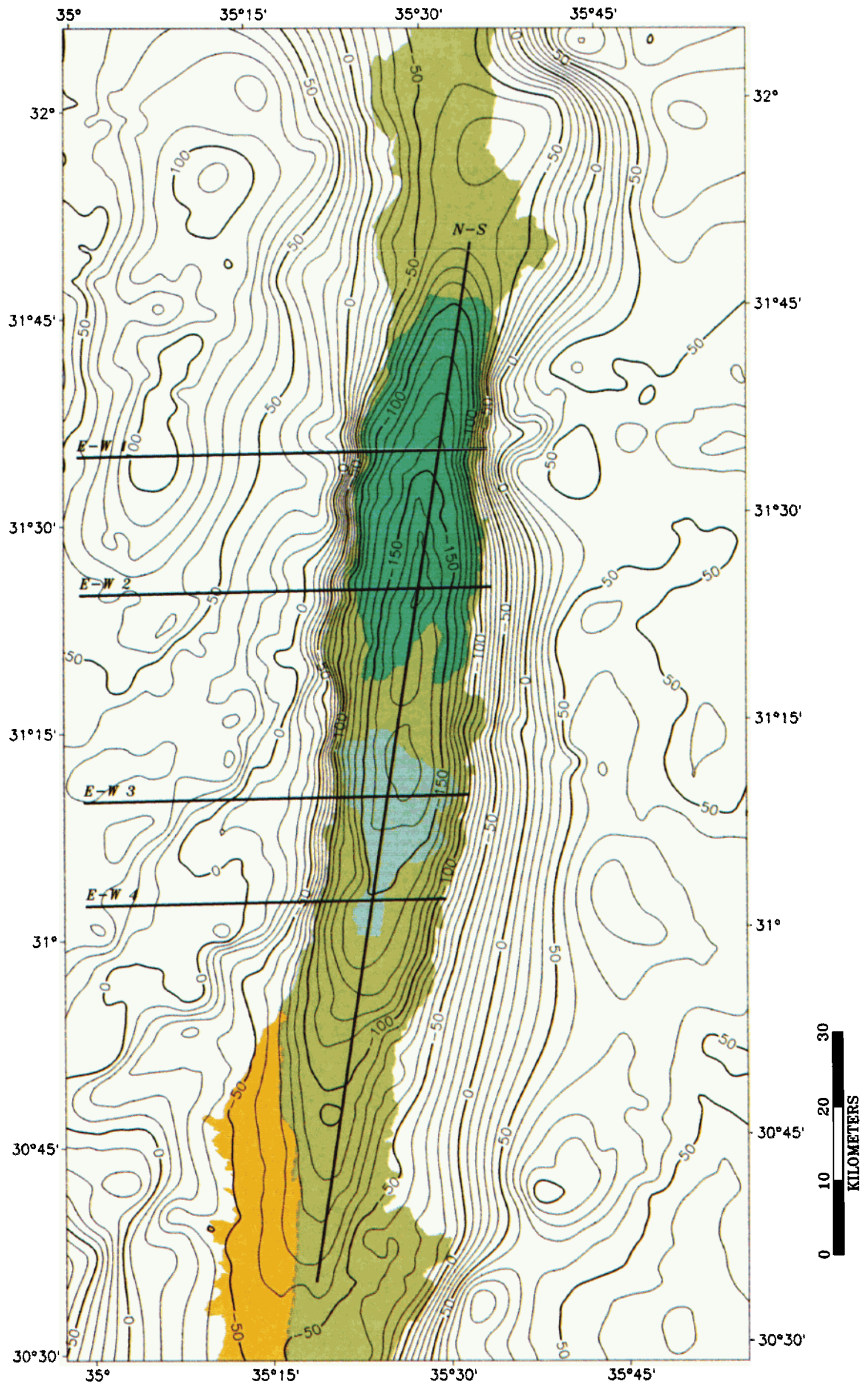




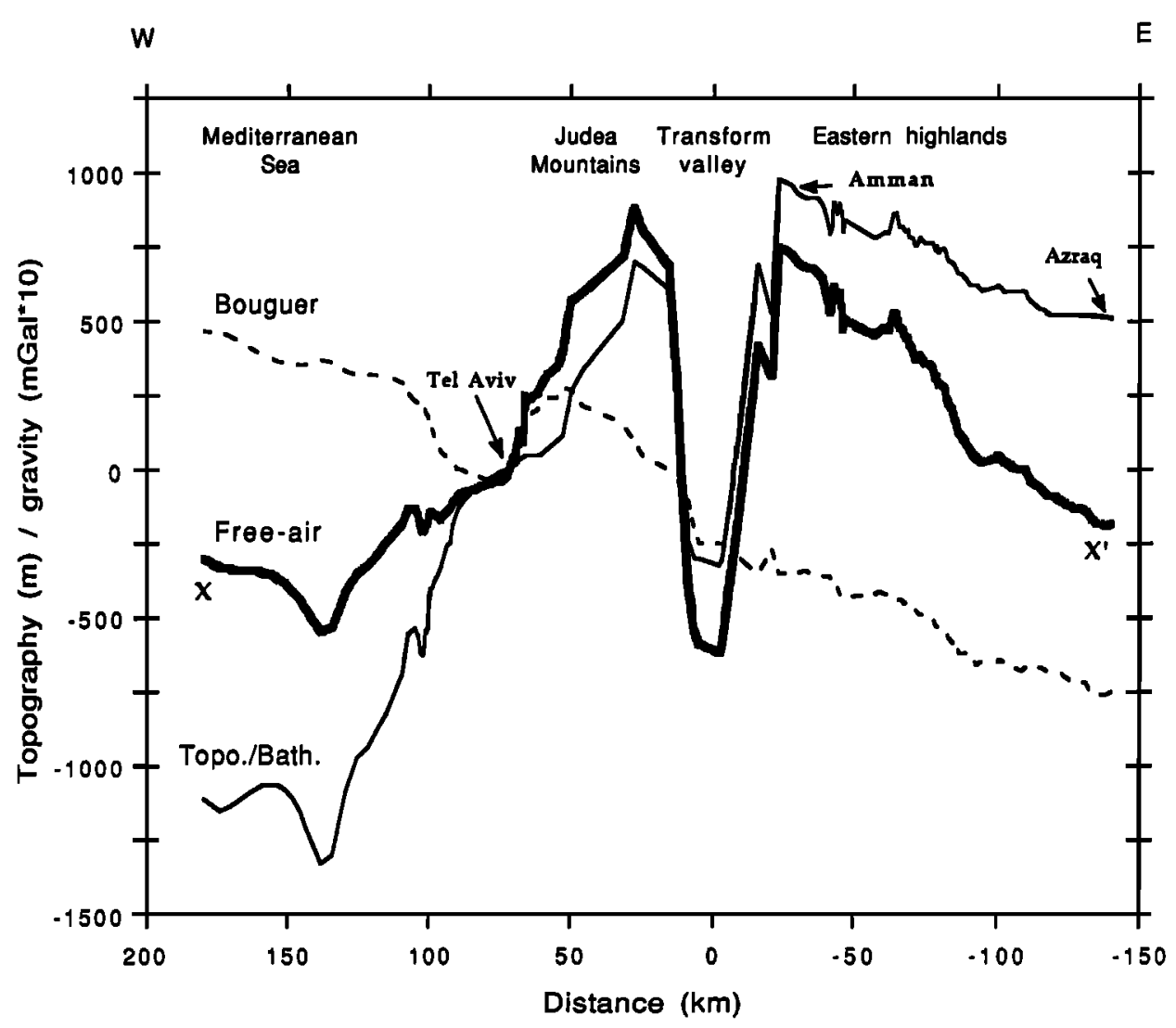

Fig. 3. Regional profile X-X' of topography (dashed line), free-air gravity (heavy line), and Bouguer gravity (thin line) anomalies across the Dead Sea transform outside the basin [after ten Brink et al., 1990]. See Figure 1 for location. Bouguer anomaly was calculated with a density of $2670 \mathrm{~kg} / \mathrm{m}^{3}$. Note the positive correlation between topography and free-air gravity and the lack of Bouguer anomaly under the transform valley.

wavelengths $(<60 \mathrm{~km})$; hence the free air gravity anomaly map primarily reflects the topography; the axis of the Judea Mountains shows as a high $(<100 \mathrm{mGal})$ gravity anomaly in the NW corner of the map, the NE-SW monoclines are identifiable farther south as NE trending steps in the gravity field, and the free-air gravity anomalies over the eastern highlands are fairly flat. The long-wavelength component of the gravity field consists of a regional trend decreasing to the east and is prepresented by the Bouguer anomaly (Figure 3). It was modeled by ten Brink et al. [1990] to result from crustal thickening from $\leq 12 \mathrm{~km}$ in the Mediterranean Sea to $35 \mathrm{~km}$ in the Arabian desert, the majority of which probably occurs west of the basin (Plate 3). The regional trend is apparent in the free-air map only when peak-to-trough differences are compared. The maximum peak-to-trough difference between the Judea Mountains and the Dead Sea ( $335 \mathrm{mGal}$ ) is $100 \mathrm{mGal}$ larger than that between the Moab Plateau and the Dead Sea (Plate 2), although both flanks are at similar elevations (Plate 1).

Plate 2. (Opposite) Free-air gravity anomaly map of the Dead Sea basin and its vicinity gridded from the gravity stations in Plate 1 at $500 \mathrm{~m}$ square cell size and smoothed. Contour interval is 10 $\mathrm{mGal}$. Heavy lines are locations of four east-west and one northsouth gravity profiles (Figures 5 and 6). Colors are similar to Plate 1.

\section{Bouguer Gravity ANOMALy AND ITS FIRST DeRIVATIVE}

Bouguer gravity correction is an effective way of removing the gravitational influence of local (short wavelength) topography. Variable-density Bouguer correction was applied because surface geology in the area is well known and fairly uniform. Following density measurements by Folkman [1976], two densities were chosen for the Bouguer correction in Plate $3: 2550 \mathrm{~kg} / \mathrm{m}^{3}$ for all the points shallower than $250 \mathrm{~m}$ bsl (generally, the carbonate cover outside the transform valley), and $2150 \mathrm{~kg} / \mathrm{m}^{3}$ for all the points deeper than $250 \mathrm{~m}$ bsl (generally, the Quaternary sediments inside the valley). A small artificial step of $2.65 \mathrm{mGal}$ across the elevation contour of $-250 \mathrm{~m}$ is introduced by the variable-density Bouguer correction, but this step is small compared to the amplitude of Bouguer anomalies in the basin. Dead Sea water density, $1280 \mathrm{~kg} / \mathrm{m}^{3}$, was calculated from its salinity and temperature [Fonofoff and Millard, 1983] and replaced with the density of sediments in the valley, $2150 \mathrm{~kg} / \mathrm{m}^{3}$. The density of evaporites was taken to be the same as the rest of the sediments filling the basin, because of the absence of Bouguer gravity anomaly over the Mount Sedom salt diapir (Figure 2), which is surrounded by basin-fill sediments. The Bouguer anomaly map was calculated at a datum of $408.13 \mathrm{~m}$ bsl (lake level during the experiment).

A negative anomaly of up to $100 \mathrm{mGal}$ below the surround- 


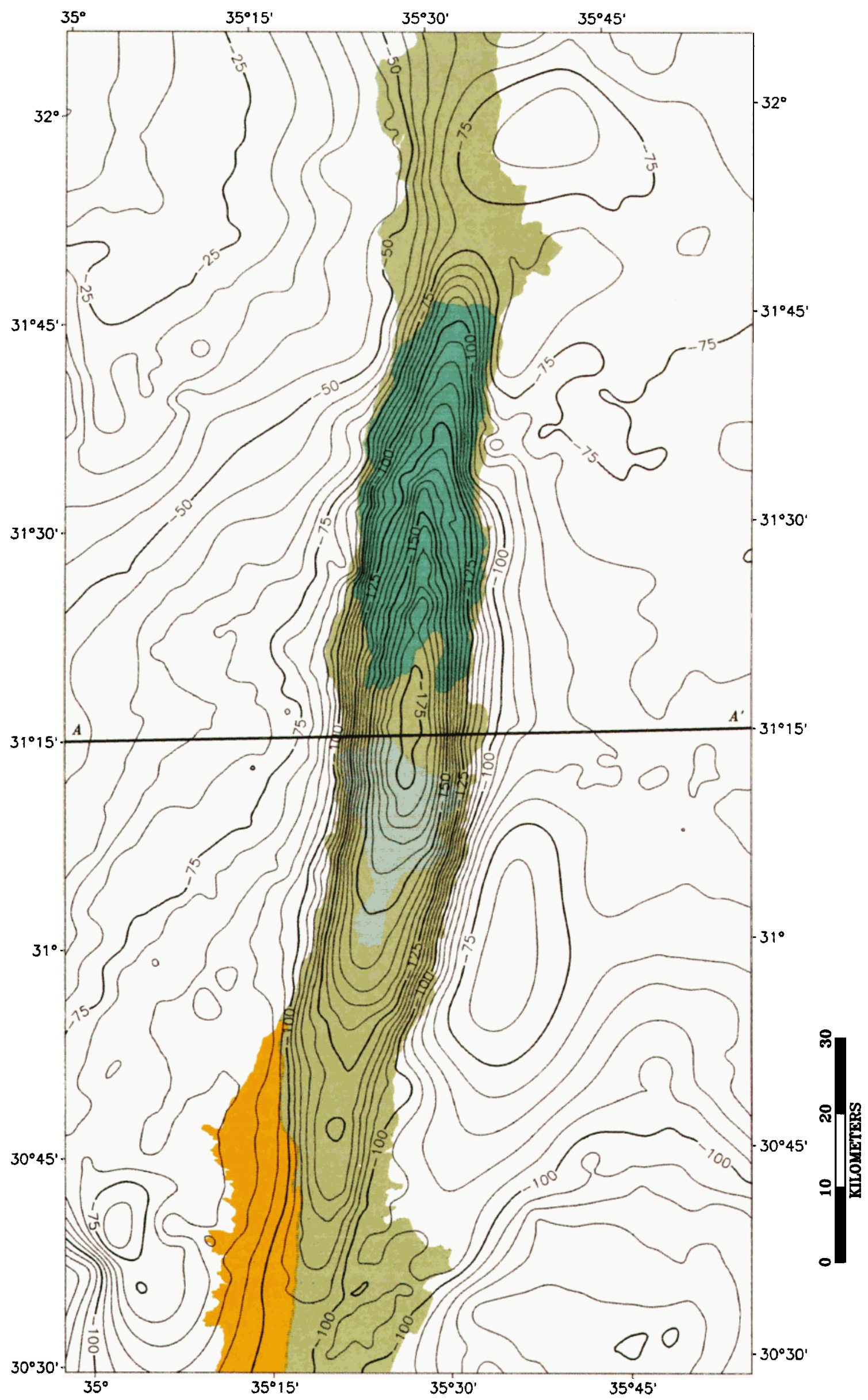



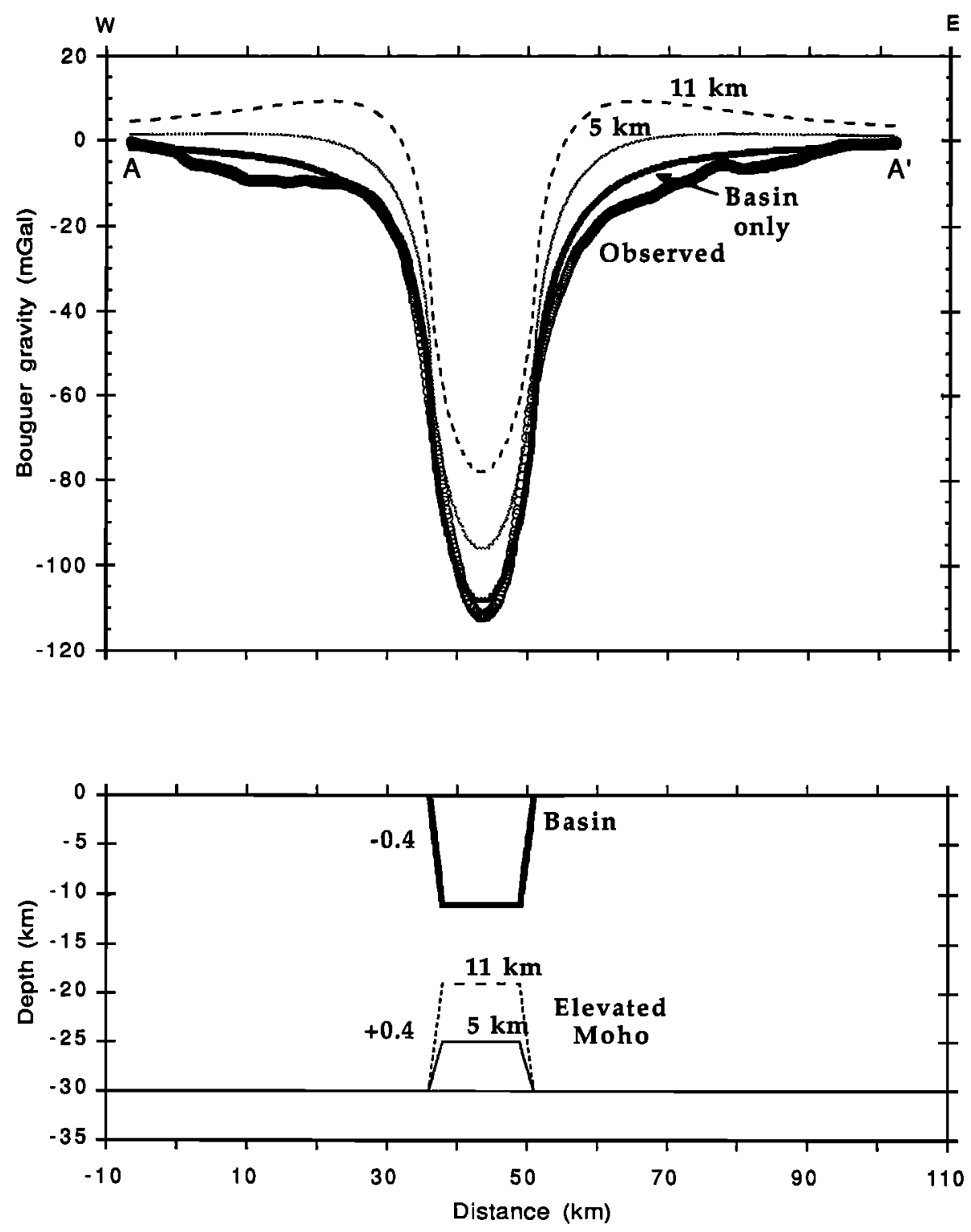

Fig. 4. (top) Bouguer anomaly profile A-A' (circles) across the center of the Dead Sea basin extracted from Figure 3 and calculated anomalies (top). (bottom) Simple density models. Heavy line is anomaly arising from a trapezoid representing the basin with negative density contrast of $0.4 \times 10^{3} \mathrm{~kg} / \mathrm{m}^{3}$ between basin fill and surrounding carbonate platform. Note that the trapezoid representing the basin is symmetric and is located between the observed western and eastern boundary faults of the basin. Thinner lines are anomaly arising from the basin plus trapezoids representing mantle intrusion into the lower crust with positive density contrast of $0.4 \times 10^{3} \mathrm{~kg} / \mathrm{m}^{3}$. Intrusion to $11 \mathrm{~km}$ above the surrounding Moho represents complete local Airy isostatic compensation and intrusion to $5 \mathrm{~km}$ above surrounding Moho represents partial compensation. Mantle intrusion generates slightly positive anomalies at the flanks of the basin, which are not observed.

ing values defines the areal extent of the Dead Sea Basin (Plate 3). The anomaly is confined to within the transform valley, particularly on the west side, suggesting that the depocenter is significantly narrower than the width of the valley and is located in the eastern part of the basin. The

Plate 3. (Opposite) Bouguer gravity anomaly map of the Dead Sea basin and its vicinity gridded at $500 \mathrm{~m}$ square cell size and smoothed. Densities used for Bouguer corrections are [after Folk$\operatorname{man}, 1976] 2150 \mathrm{~kg} / \mathrm{m}^{3}$ below $250 \mathrm{~m}$ bsl and $2550 \mathrm{~kg} / \mathrm{m}^{3}$ above 250 bsl. Reference level for map is lake level during the experiment $408.13 \mathrm{~m}$ bsl. Contour interval is $5 \mathrm{mGal}$. Heavy line is location of Figure 4. Colors are similar to Plate 1. minimum anomaly is fairly flat and centered around the Lisan peninsula. To the south, a gradient in the Bouguer anomaly at $\sim 30^{\circ} 55^{\prime} \mathrm{N}$ marks the point where the basin becomes considerably shallower and another gradient at $\sim 30^{\circ} 40^{\prime} \mathrm{N}$ marks the southern termination of the basin. To the north, the basin ends about $5 \mathrm{~km}$ north of the lake. The constant gravity gradient at the northern end precludes the existence of a large normal fault there.

A profile across the deepest part of the basin shows a symmetric negative anomaly that can be fit by an $11-\mathrm{km}$ deep symmetric basin with a negative density of $400 \mathrm{~kg} / \mathrm{m}^{3}$ between the basin fill and the carbonate platform (Figure 4). This profile is also indicative of the deep structure and the 


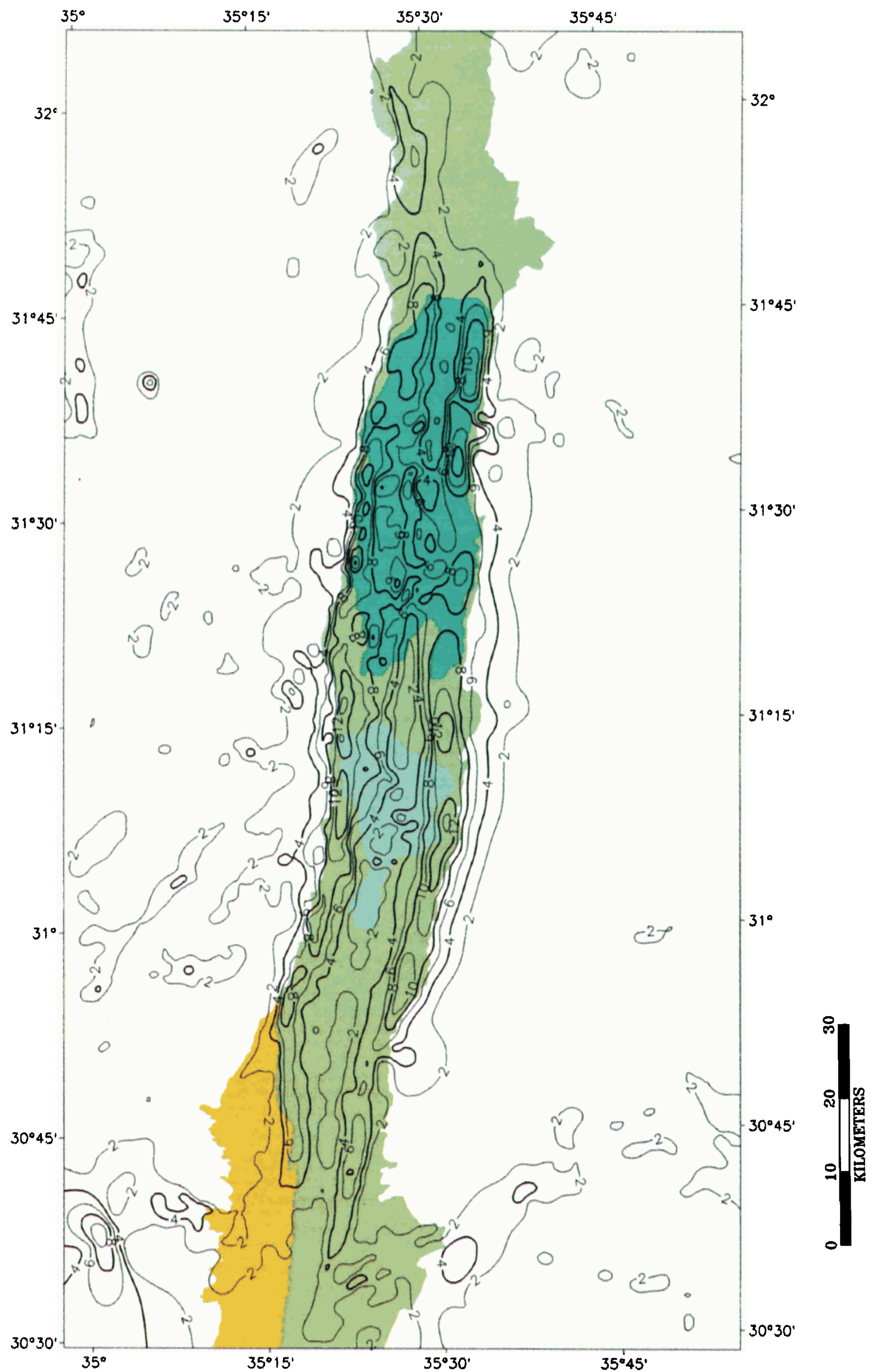


isostatic compensation of the basin. In local isostasy, the low density of the basin fill should be offset by high-density mantle material. The intruding mantle material under the basin would show as a positive gravity anomaly with a longer wavelength than the negative anomaly due to the basin fill; hence the sum of the anomalies would create a broad positive anomaly on both sides of the negative basin anomaly. The observed anomaly is negative throughout the profile and monotonically decreasing toward the basin (Figure 4), suggesting that the Moho is probably not significantly elevated under the deepest part of the basin, and the basin is not locally compensated. Finally, there is no Bouguer gravity anomaly associated with the transform valley north of the lake (Figure 3 and Plate 3), indicating that outside the basin the Moho is also not elevated.

A first derivative map (Plate 4) emphasizes the short wavelength features of the Bouguer anomaly. The absolute horizontal derivative $\left((\partial g / \partial x)^{2}+(\partial g / \partial y)^{2}\right)^{0.5}$ was smoothed using a median filter with a diameter of $2 \mathrm{~km}$. The basin is bounded on the eastern and western sides by two "crests" connecting zones of maximum gravity gradient. The crests become closer to each other, but do not meet at the southern and northern ends. A linear "valley" connecting zones of minima is enclosed between the high-gradient crests (except in a $\sim 20-\mathrm{km}$ long area north of the Lisan peninsula) and probably marks the axis of the deepest part of the basin. There are a few minor offsets along the valley of low gradient, which may be attributed to subsurface diagonal faults.

Provided the crests of maximum gradient represent faults, the skewness of the horizontal gravity gradient around the peak gradient (i.e., the shape of the second derivative) can be used to deduce the dip of the fault [Bott, 1962]. A vertical fault will produce a symmetric peak, a reverse fault will produce a steeper slope toward the basin, and a normal fault will produce a steeper slope toward the flank. The eastern crest appears to represent a generally vertical or slightly reversed fault, whereas the western crest represents a generally normal fault, except at the northernmost end (north of latitude $31^{\circ} 37^{\prime} \mathrm{N}$ ) where it is a vertical to reverse fault. The northernmost end of the western crest follows the trace of the Dead Sea strike-slip fault which is indeed slightly reversed [Rotstein et al., 1991].

In summary, the Bouguer and first derivative maps (Plates 3 and 4) outline the horizontal dimensions, the locations of the faults bounding the basin along the east and west sides, and the absence of faults at the northern and southern ends. A Bouguer profile across the basin (Figure 4) suggests that the basin is symmetric and that Moho is probably not significantly elevated under the basin. Positive correlation between the free-air anomaly and the topography (Plate 2 and Figure 3) at wavelengths $<60 \mathrm{~km}$ indicates that the basin is probably not compensated locally.

\section{Gravity Models}

We calculated two-dimensional (2-D) gravity models along four east-west profiles across the basin (Figure 5) and a 2

Plate 4. (Opposite) Map of the magnitude of the first horizontal derivative of the Bouguer anomaly. Map emphasizes the shortwavelength features in the Bouguer map (Plate 3). Contour interval is $2 \mathrm{mGal} / \mathrm{km}$. Colors are similar to Plate 1 . 1/2-dimensional (2 1/2-D) model [Campbell, 1983] for one north-south profile along the basin (Figure 6) and compared them with free-air gravity profiles. Two and one halfdimensional modeling of the north-south profile was necessary, because the width-to-depth ratio of the basin (the source of mass) is small (2-D gravity models assume that the modeled mass under the profile extends to an "infinite" distance on either side of the profile). The models consisted of only four densities: the Dead Sea water $\left(1280 \mathrm{~kg} / \mathrm{m}^{3}\right)$, the sediment fill $\left(2150 \mathrm{~kg} / \mathrm{m}^{3}\right)$, the Mesozoic carbonate platform $\left(2550 \mathrm{~kg} / \mathrm{m}^{3}\right)$, and the crystalline basement $\left(2670 \mathrm{~kg} / \mathrm{m}^{3}\right) . A$ basic requirement in the modeling was that the structure of the east-west profiles and the north-south profile should be identical at their crossing points. In addition, the width of the 26 prismatic bodies in the $21 / 2-\mathrm{D}$ model were constrained by the width of the basin at various depths from the east-west models. The models used all the available geological and geophysical information including bathymetry, location of faults in surface geology [Picard and Golani, 1965; Bentor et al., 1965] and seismic data [e.g., Neev and Hall, 1976; Kashai and Crocker, 1987; ten Brink and Ben-Avraham, 1989; Rotstein et al., 1991], the gravity gradient map (Plate 4), and the depth to crystalline basement west and east of the basin from seismic refraction data [Ginzburg and Folkman, 1981; El-Isa et al., 1987]. The latter is completely unknown under the basin. We assumed that the thickness of the Paleozoic-Mesozoic section under the basin is similar to that under the western flank $(5-8 \mathrm{~km})$ in order to minimize the depth of the basin. If instead, a thickness similar to that under the eastern flank $(2-3 \mathrm{~km})$ is assumed, the modeled basin would be deeper.

Several features are consistent in all the models for the east west profiles (Figure 5): A full graben or close to a full graben occupies the eastern part of the basin. The faults bounding the full graben have close to vertical $\left(>80^{\circ}\right)$ dips. Tilted fault blocks, several kilometers wide, are located along the western side of the basin and smaller tilted blocks may be located on the eastern side. Following the available seismic observations [Neev and Hall, 1976; Kashai and Crocker, 1987; ten Brink and Ben-Avraham, 1989], the western blocks in profiles EW3 and EW4 were modeled as 3to 4-km-deep step blocks, whereas in profiles EW1 and EW2 the western blocks were modeled as tilted from the surface. The total width of the basin is $15-17 \mathrm{~km}$ in profiles EW2, EW3, and EW4 and $13 \mathrm{~km}$ in EW1, in accord with surface geology; and the width of the full graben is $10-12 \mathrm{~km}$ in profiles EW2, EW3, and EW4 and $8.5 \mathrm{~km}$ in EW1, in accord with seismic data [Neev and Hall, 1976; Kashai and Crocker, 1987; ten Brink and Ben-Avraham, 1989].

A narrow ( $3 \mathrm{~km}$ wide) negative anomaly is superimposed on the gravity anomaly within the basin in profile EW2. On the Bouguer map (Plate 3 ) this anomaly shows as a northsouth oriented trough extending north of the Lisan. The origin of this anomaly is unclear, but its narrow width requires the source of this anomaly to be located close to the lake floor. One possibility is that the seafloor along this anomaly is not flat, as the echo sounder shows. Instead of bottom reflections the acoustic waves may be reflecting off the flat top of a brine layer.

Several features are worth noting in the gravity anomaly and model along the N-S profile (Figure 6). First, the gradual decrease in the gravity from the northern and the southern ends of the basin indicates that the basin sags from the two 

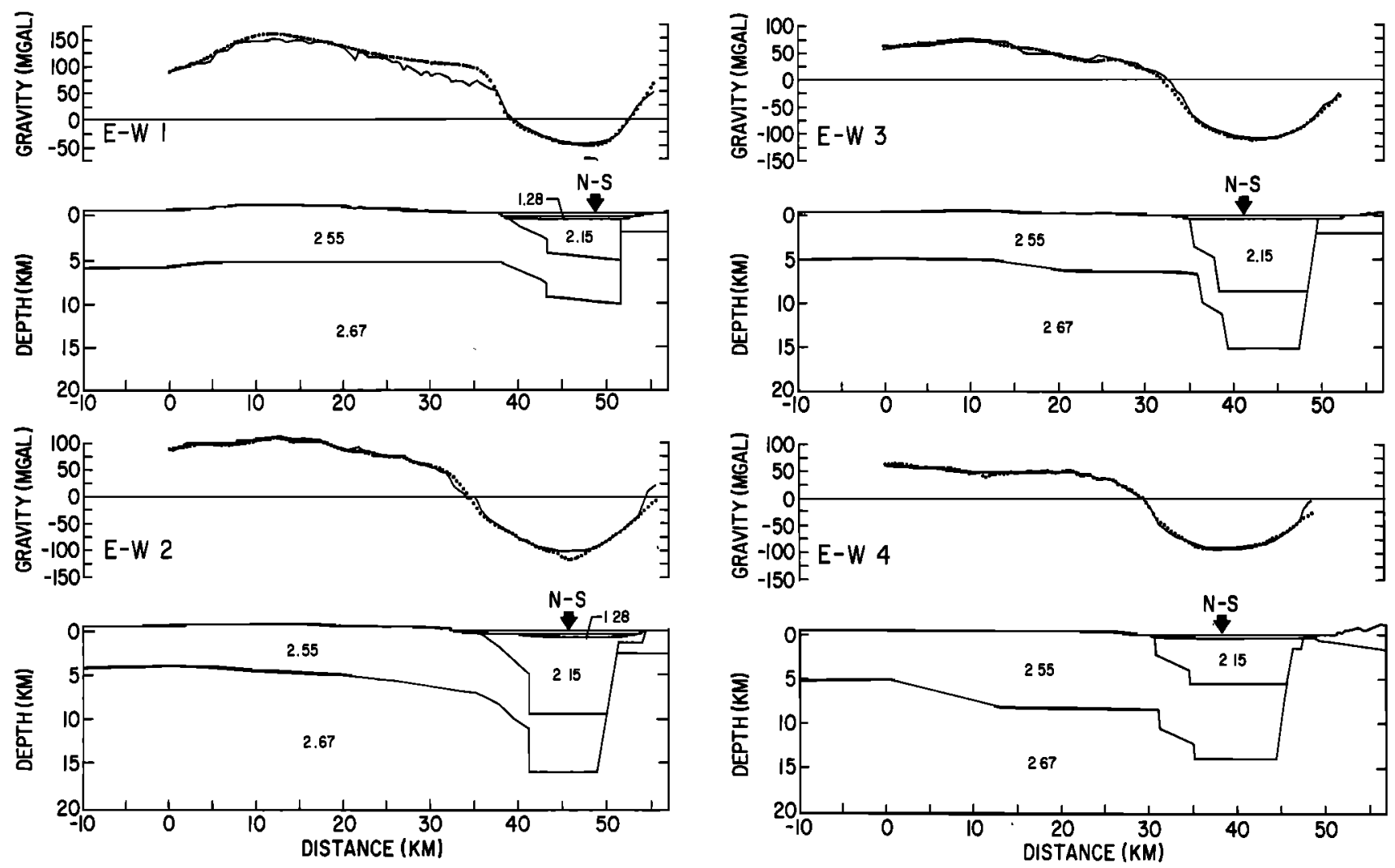

Fig. 5. Four east-west free-air gravity profiles (dotted lines, see Plate 2 for location) extracted from the gridded free-air gravity data shown in Plate 2, compared with calculated gravity (solid lines) from two-dimensional densitydepth models (below the profiles). Density in $1 \times 10^{3} \mathrm{~kg} / \mathrm{m}^{3}$. Heavy arrow is location of crossing of north-south gravity profile. Distance is measured east of longitude $35^{\circ} 00^{\prime} \mathrm{E}$. Topography was digitized from 1:100,000 topographic maps with contour interval of $20 \mathrm{~m}$. Linear trend of $0.69 \mathrm{mGal} / \mathrm{km}$ was subtracted from profiles EW2, EW3, and EW4 in accord with the thickening of the continental crust away from the Mediterranean Sea. A trend of $1.28 \mathrm{mGal} / \mathrm{km}$ was subtracted from profile EW1 to achieve a reasonable fit. The remaining misfit on the western flank in EW1 is due to lack of data, which led to erroneous interpolation of the grid.

ends and that northern and southern boundary faults are not detectable. Second, the basin is slightly asymmetric along its axis with the deepest part of the basin located north of the midpoint. Third, the basin has three depth levels, the deepest level, 8-10 km, is located under the Lisan and part of the salt pans, an intermediate level (5-6 km) extends $\sim 20 \mathrm{~km}$ to the north and to the south of the deep level, and a shallow level $(2 \mathrm{~km})$ occupies the southernmost $30 \mathrm{~km}$. The three depth levels are probably separated by fault zones, although the model is not capable of resolving the individual faults.

In summary, the gravity models are consistent with the geometry of the basin as a full graben with collapsed side blocks, high-angle faults, relative north-south symmetry, and the lack of faults at the northern and southern end. The models indicate that the basin may reach a depth of $10 \mathrm{~km}$ under Lisan Peninsula.

\section{STRUCTURAL Synthesis}

A synthesis of the 3-D structure of the Dead Sea basin from the free-air, Bouguer, and first derivative maps, and from the gravity models is shown in Figure 7. The "crests" of maximum gravity gradient delineate the eastern and western boundary faults of the basin whereas the "valley" of the minimum gravity gradient delineates the axis of the full graben. The crests of maximum gravity gradients do not close on the southern and northern ends of the basin, and the valley of minimum gradient continues past the modeled ends of the basin, suggesting that there are no diagonal fault offsets there. Although the crests do not meet, they become closer to each other at the northern and southern ends, indicating that the basin narrows at its ends where it is also the shallowest $(<3000 \mathrm{~m})$. This suggests that widening by the collapse of blocks accompanies the deepening of the basin. Seismic data show [ten Brink and Ben-Avraham, 1989, Figure 4] that these blocks are inclined toward the center of the basin rather than away from it, indicating that they are collapse structures, not the rotating blocks characteristic of extensional regimes.

The western high gradient crest between latitudes $31^{\circ} 00^{\prime} \mathrm{N}$ and $31^{\circ} 37^{\prime} \mathrm{N}$ (Figure 7) runs parallel and about $1 \mathrm{~km}$ eastward of the escarpment that marks the western boundary of the basin, supporting the interpretation that the escarpment is the surface expression of a normal fault [Picard and Golani, $1965 ;$ Bentor et al., 1965]. South of $30^{\circ} 56^{\prime} \mathrm{N}$ the western crest deviates from the escarpment and follows the contact between the Miocene Hazeva Formation and the Quaternary fill (Plate 4). The location of the western crest along the contact outlines a buried fault with 1-2 km of vertical offset which separates the basin fill from the carbonate platform under the thin $(<600 \mathrm{~m})$ Hazeva cover [ten Brink and 


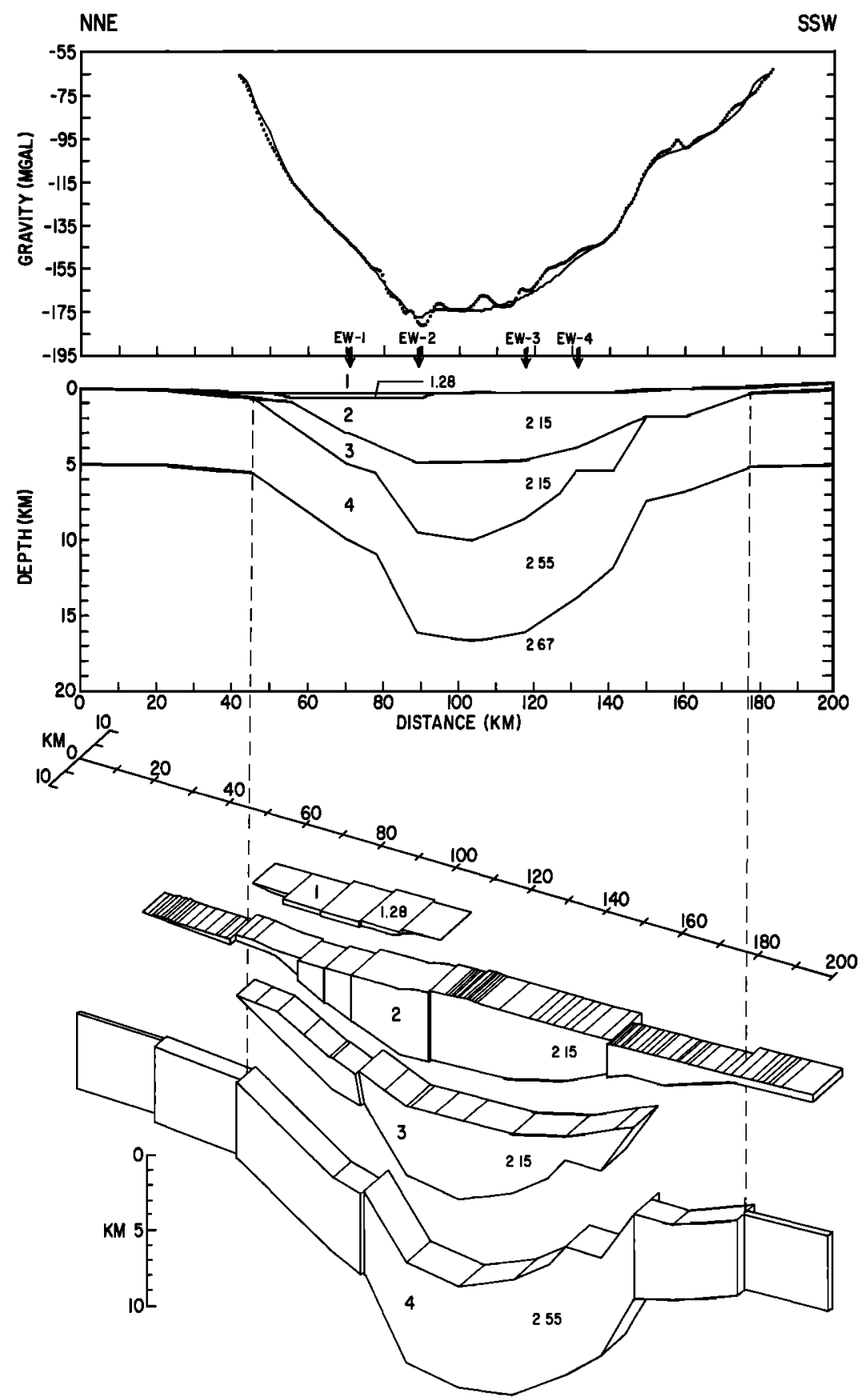

Fig. 6. (top) Free-air gravity profile along the axis of the basin (dotted line) extracted from the gridded free-air gravity data shown in Plate 2, compared with calculated gravity (solid line) from a 2 1/2-dimensional density-depth model. No trend was subtracted from the N-S profile. (middle) Cross section of the model along the profile. (bottom) Projection of the model showing the widths of the prisms used to calculate the model. Total of 26 prisms were used to approximate the three-dimensional structure of the basin. Model was constrained by the east-west profiles and by other geological and geophysical data (see text). Dashed lines are locations of the northern and southern ends of the basin. Density of prisms is in $1 \times 10^{-3} \mathrm{~kg} / \mathrm{m}^{3}$. Water density (body 1) in the $21 / 2$-dimensional model was contrasted against carbonate platform $\left(2550 \mathrm{~kg} / \mathrm{m}^{3}\right)$ on both sides of the lake, sediment density at shallow level (body 2) was contrasted against carbonate platform west of the basin, and basement $\left(2670 \mathrm{~kg} / \mathrm{m}^{3}\right)$ east of the basin; deeper sediment fill (body 3) against basement on both sides, and Mesozoic sediments underlying the basin (4) against basement.

Ben-Avraham, 1989, Figure 5]. The gradual southward decrease in the amplitude of the western crest indicates that the vertical offset on the fault diminishes toward the southern end of the basin.

The northern part of the eastern high gradient crest is located within the lake and follows the base of the bathy- metric slope $(-700 \mathrm{~m}$ isobath, Figure 7$)$. Northward it disappears about $5 \mathrm{~km}$ north of the lake shore. To the south, the eastern crest crosses the Lisan peninsula and the salt pans without a clear topographic or geologic expression and then continues subparallel to the surface trace of the Dead Sea transform [Picard and Golani, 1965; Bentor et al., 1965]. 


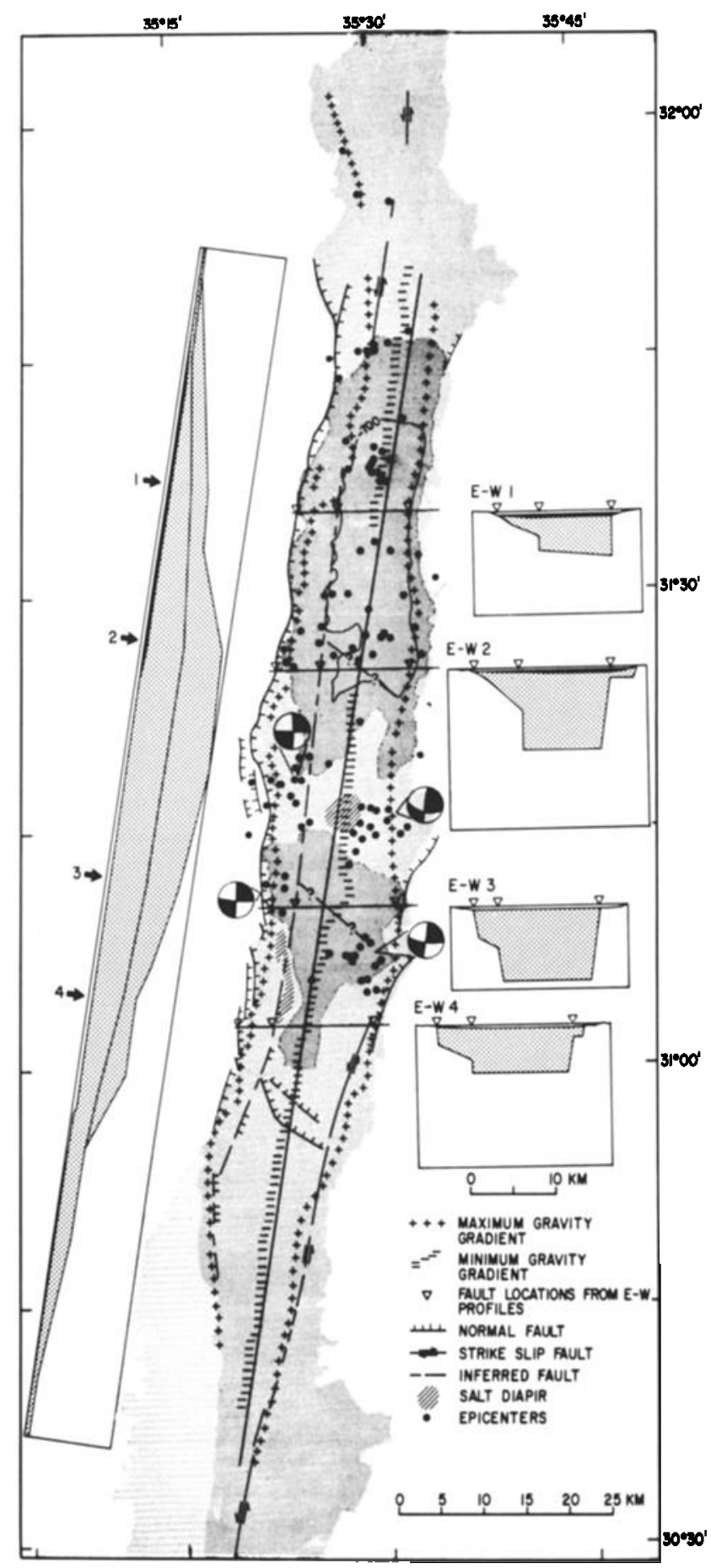

Fig. 7. Structural interpretation map of the Dead Sea basin. Solid lines-locations of east-west and north-south profiles. Models corresponding to these profiles are shown on both sides of the map of the basin (water-black, sediment fill-dotted area). Arrows along N-S profile-locations of crossings of E-W profiles. Composite earthquake solutions (balls), and epicenter locations (dots) after van Eck and Hofstetter [1989]. Surface fault locations after Picard and Golani [1965], Bentor et al. [1965], and Reches and Hoexter [1981] and subsurface fault locations after Neev and Hall [1976] and ten Brink and Ben-Avraham [1989]. Dark shade-lake and salt pans; lighter shade-Quaternary rock cover within the valley; lightest shade-Miocene Hazeva Formation within the valley.

The deviation of the eastern crest from the surface trace of the strike-slip fault indicates that at least near the surface, subsidence along the fault occurs in short discontinuous segments. Note that the eastern crest continues south past the end of the basin, implying that shallow depressions exist along the fault even outside the basin.

Less apparent in the gravity gradient map (except north of $31^{\circ} 37^{\prime} \mathrm{N}$, Plate 4) is the fault that delimits the full graben on the west. We refer to this fault as "the western longitudinal fault." Our suggested trace of the western longitudinal fault follows the $-700 \mathrm{~m}$ isobath within the lake (Figure 7) and is similar to previous suggestions [Neev and Hall, 1976; Kashai and Crocker, 1987]. Geographically, it appears to be the continuation of the observed trace of the Dead Sea strike-slip fault north of the lake [Reches and Hoexter, 1981]. The western longitudinal fault is observed in seismic lines [Neev and Hall, 1976; ten Brink and Ben-Avraham, 1989] and is compatible with the gravity models (Figure 5). According to the seismic lines and the gravity models, the fault is vertical or slightly reversed [e.g., ten Brink and Ben-Avraham, 1989, Figure 4].

Composite solutions of earthquake clusters indicate a possible strike-slip motion along the western longitudinal fault as far south as $31^{\circ} 10^{\prime} \mathrm{N}$ [van Eck and Hofstetter, 1989]. Earthquake solutions on the eastern side of the graben indicate strike-slip motion as far north as $31^{\circ} 15^{\prime} \mathrm{N}$, suggesting some overlap between the northern and southern strands of the Dead Sea faults in the Lisan peninsula area. The gravity models show that this area is indeed the deepest part of the Dead Sea basin. The high gravity gradients within the basin immediately north of the Lisan peninsula may indicate that active subsidence is also taking place there. Although the lake bottom north of the Lisan appears to be flat, the subsurface in this local area (known as the Arnon Sink) is characterized by an accelerated asymmetric subsidence and sediment accumulation [Neev and Hall, 1976].

The valley of minimum gravity gradient can be divided into five segments, each $25-30 \mathrm{~km}$ long (Plate 4), which may represent segmentation of the basin. From south to north these are the area south of Amaziahu escarpment (fault), the southern salt pans (north of the fault), the Lisan, the high gravity gradient area immediately north of the Lisan, and the low gravity gradient area farther north (Plate 4). These segments roughly coincide with those suggested earlier based on seismic data [ten Brink and Ben-Avraham, 1989]. The southernmost two segments appear to be outside the region of en echelon overlap, but one of them (the southern salt pans) continues to subside rapidly [ten Brink and BenAvraham, 1989].

\section{Crustal Stretching and Isostatic Compensation}

The simplest model for the evolution of the Dead Sea basin is an extension across a jog between two strike-slip fault strands, which created a rhomboid hole bounded by diagonal normal faults [Freund and Garfunkel, 1976]. More recent models suggested along-axis asymmetric extension over a midcrustal detachment fault. In these models the southern end of the basin is bounded by a large diagonal listric fault, whereas the northern end warps down [Arbenz, 1984; Reches, 1987]. The Amaziahu listric fault was considered the southern diagonal fault [Arbenz, 1984]; however, the listric fault flattens into a salt layer within the basin fill and is underlain by high-angle normal faults in the basement [ten Brink and Ben-Avraham, 1989]. Moreover, the detachment model implies that the formation of the strike-slip basin is confined to the upper crust (thin-skinned deformation). Although such a model can be applied to extension over 


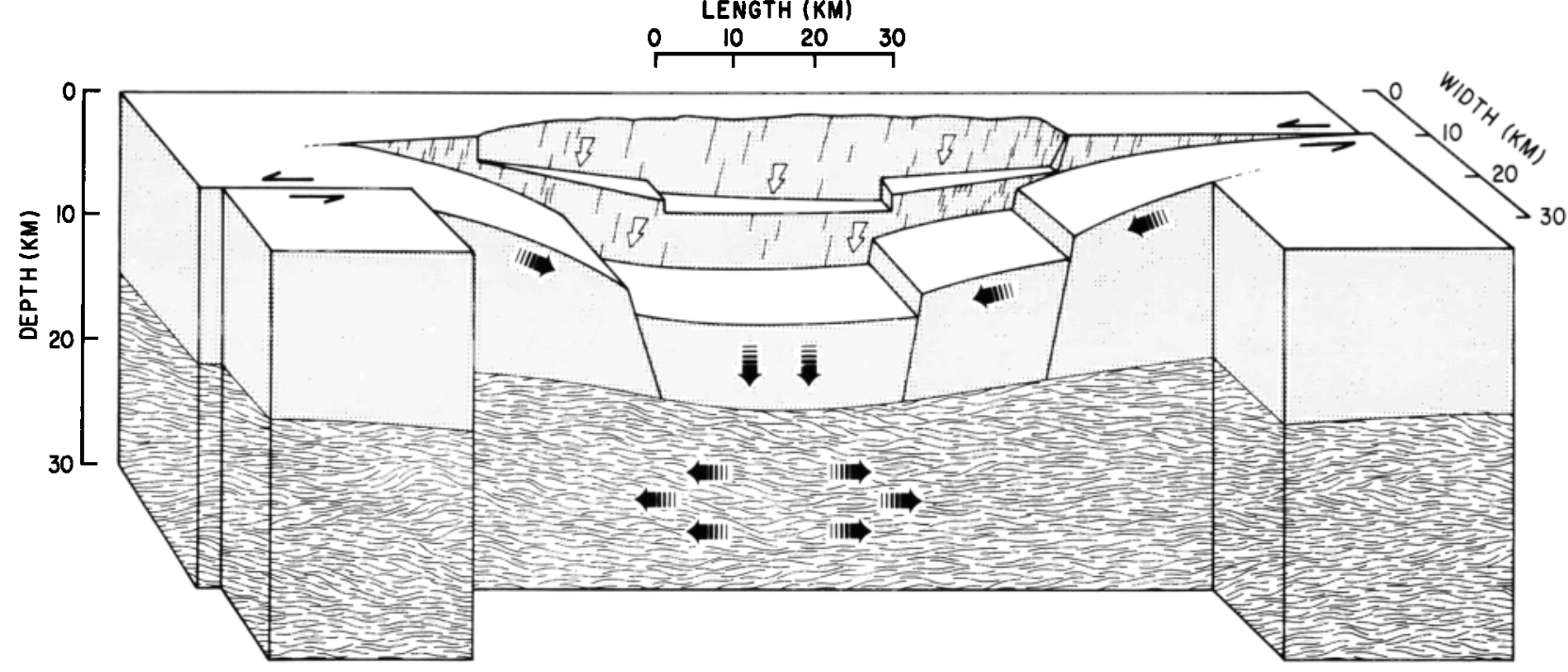

Fig. 8. Conceptual model for the opening of the Dead Sea pull-apart basin. Stretching parallel to the strike-slip fault strands takes place in the brittle upper crust and the ductile lower crust and is focused at the center of the basin where the basin is the deepest. The northern and southern ends sag into the deepest part of the basin and are narrower. Collapse of the side walls along the deep part of the basin created blocks that are tilted toward the basin. These blocks give the appearance of a half-graben profile across the basin, although the pull-apart basin itself is a full graben.

reactivated nappes (e.g., Vienna Basin [Royden, 1985]), it is probably not applicable to the Dead Sea basin area where the geological history is different.

Several authors interpreted the eastward dipping geometry of the collapsed blocks along the west side of the basin as representing the shape of the entire basin and concluded that it is a half graben [Zak and Freund, 1981], caused by a transform-normal extension [Ben-Avraham and Zoback, 1992]. However, with the exception of the local Arnon Sink, seismic reflectors east of the collapsed blocks are horizontal [e.g., Neev and Hall, 1974, Figures $3 a$ and 6; ten Brink and Ben-Avraham, 1989, Figures 4, 5a, 7, and 8], and the Bouguer gravity anomaly (Figure 4) and the gravity models (Figure 5) are consistent with a full graben model.

It is puzzling, however, that the collapsed blocks occur mostly on the west side of the graben. The maximum tensile stress, $\Delta \sigma x x$, on the walls of the basin is 200 bars on the west side and 230 bars on the east side $(\Delta \sigma x x=0.5 d \rho g h$ [Turcotte and Schubert, 1982], where $d \rho$ is the density contrast between the basin fill and the surrounding rock, 400 $\mathrm{kg} / \mathrm{m}^{3}$ and $460 \mathrm{~kg} / \mathrm{m}^{3}$, and the maximum depth $h$ is $10 \mathrm{~km}$ ). Casting the sediment overburden and the tensile stresses in terms of the resolved shear and normal stresses on boundary faults with an angle of $60^{\circ}$ [Turcotte and Schubert, 1982], we find that the tensile stresses due to density contrast across both walls of the basins are not enough to overcome the static friction [Byerlee, 1978] and cause block collapse on the west side. We suggest that the collapse was facilitated by the existence of normal faults that separate the transform valley from the uplifted highlands (Figure 7). The width of the pull-apart basin (the full graben) and its location along the eastern side of the valley were determined by the locations of the strike-slip fault strands. The asymmetric location of the basin within the valley resulted in the western part of the valley being wedged between the full graben and the normal fault that separates the valley from the western highlands (the western boundary fault). Subsidence of the graben created local tensile stresses, which activated the normal fault leading to the collapse of the western part of the valley into the basin.

Our scenario for the opening of the Dead Sea basin is presented in Figure 8. Local extension of the upper crust in the N-S direction is concentrated in the deepest part of the basin (around the Lisan peninsula) where the two strands of the strike-slip fault possibly overlap. Local extension may also currently occur at the northern end of the eastern strand north of the Lisan where anomalous gravity gradient and rapid subsurface subsidence (the Arnon Sink) are observed. Outside the area of concentrated extension the basin simply sags toward the hole. The sagging indicates that the upper crust lost its foundation over a wider area than just the deepest part of the basin. This could happen if the ductile part of the crust also stretched and necked under the basin and if the brittle crust had a finite rigidity. Deformation of both the brittle upper crust and the ductile lower crust is expected because the Dead Sea basin is so deep $(\leq 10 \mathrm{~km})$. Extrapolation from the surrounding geology suggests that several kilometers of Mesozoic and Paleozoic sedimentary rocks underlie the basin; hence the upper crust is probably at a depth $>15 \mathrm{~km}$. Although poorly determined, earthquakes in the Dead Sea area occur probably no deeper than 12-15 $\mathrm{km}$ [van Eck and Hofstetter, 1989]. Ductile rheology is predicted to prevail below depths of $15-20 \mathrm{~km}$ in continental crusts with thicknesses and geothermal gradients similar to those around the Dead Sea [e.g., Kusznir and Park, 1987]. Thus basin-related deformation must include at least part of the semibrittle to ductile crust.

We propose that the ductile lower crust separates the deformation of the crust from that in the mantle lithosphere, because there is no evidence for upper mantle participation in the formation of the basin by either stretching, melting, or asthenospheric upwelling. Hot springs and anomalously high heat flow along the boundaries of the basin, which in other rifts indicate the existence of an anomalous heat source in the crust, were shown to be due to water seeping along faults from deeply buried aquifers under the Dead Sea basin 
[Eckstein and Simmons, 1978; Galanis et al., 1986]. Thus the geometry and deformation of the plate boundary in the mantle are unknown and may not be related to the subsidence and faulting at the surface.

A simple subsidence model supports the hypothesis that the basin formation is a crustal phenomenon. Following McKenzie [1978], the total subsidence of the basin, $S$, is composed of an initial isostatic subsidence, $S_{e}$, and thermal subsidence, $S_{t}$, due to the dissipation of the thermal perturbation that was created by lithospheric stretching. Let us assume that the lithosphere under the basin is stretched in a $10-\mathrm{km}$-wide zone. This dikelike geometry for the zone of deformed and thermally perturbed lithosphere results in lateral heat conduction and cooling of the perturbed lithosphere which is $\mathbf{2}$ orders of magnitude faster than vertical conduction which controls cooling in broad extensional sedimentary basins. The rate of lateral cooling of a dikelike thermal perturbation may be estimated by using the 1-D analytical solution for the conductive cooling of a dike with the initial conditions

$$
\begin{array}{ll}
T=T_{0} & t=0 ;-b \leq x \leq b \\
T=0 & t=0 ;|x|>b
\end{array}
$$

The solution is

$$
T(x, t)=\frac{T_{0}}{2}\left[\operatorname{erf}\left(\frac{b-x}{2(k t)^{1 / 2}}\right)+\operatorname{erf}\left(\frac{b+x}{2(k t)^{1 / 2}}\right)\right]
$$

[Lachenbruch et al., 1976], where $T_{0}$ is the thermal perturbation due to stretching, $b$ is the half width of the stretched lithosphere, and $k$ is the thermal diffusivity. Using this equation, we find that the thermal perturbation at the center of the dikelike stretched zone $(x=0 ; 2 b=10 \mathrm{~km})$ dissipates to $1 / e$ of its original strength after $1.6 \mathrm{~m}$.y. (with $k$ $=1 \times 10^{-6} \mathrm{~m}^{2} / \mathrm{s}$ ). This time is comparable with the age of the basin (<5 m.y. [Zak, 1967; Bender, 1968]). Unlike broad extensional sedimentary basins in which a significant thermal perturbation remains to be dissipated after extension, the lithosphere beneath the Dead Sea is expected to lose most of its heat during the stretching phase. Hence the observed amount of subsidence in the Dead Sea is predicted to represent, approximately, the total subsidence of the basin (initial plus thermal).

The total subsidence of a sedimentary basin after the thermal perturbation has dissipated (including sediment loading) is simply the expression for crustal thinning

$$
S=H_{c}\left(\rho_{m}-\rho_{c}\right) /\left(\rho_{m}-\rho_{s}\right)(1-1 / \beta)
$$

[McKenzie, 1978], where $\beta$ is the stretching factor of the lithosphere, $H_{c}$ is the crustal thickness, and $\rho_{m}, \rho_{c}$, and $\rho_{s}$, are the densities of the mantle, the crust, and the sediment fill, respectively. The average depth of the 132-km-long basin is $4.7 \mathrm{~km}$ below lake level and the average depth of the 71-km-long central part of the basin (deeper than $5 \mathrm{~km}$ ) is $7.57 \mathrm{~km}$ (Figure 6). For $S=4.7 \mathrm{~km}$ and $7.57 \mathrm{~km}$, the respective amounts of extensions along the Dead Sea are 40 $\mathrm{km}$ and $34 \mathrm{~km}$. Reconstruction of plate motions suggests a maximum of $30 \mathrm{~km}$ of relative motion along the Dead Sea transform since the Dead Sea basin was formed [Joffe and Garfunkel, 1987], i.e., more extension than motion along the transform.

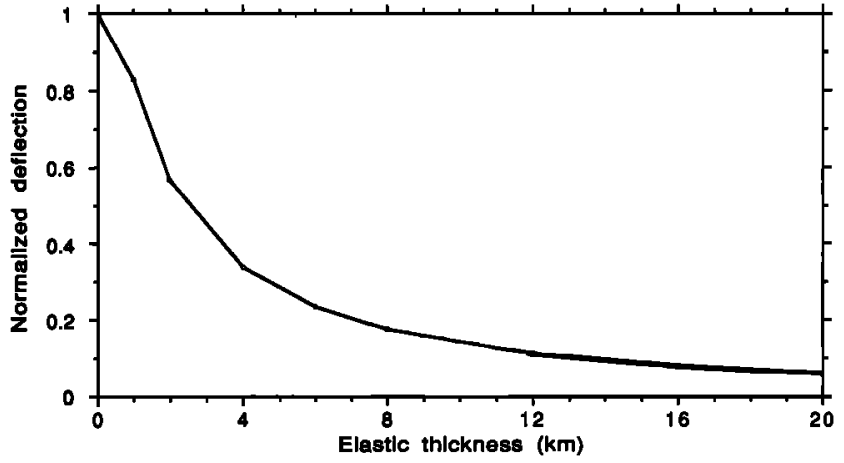

Fig. 9. Maximum deflection due to the load of the Dead Sea basin, normalized to the maximum deflection for local Airy isostasy, as a function of effective elastic thickness. Note that for an elastic thickness of $5 \mathrm{~km}$, the deflection is $<25 \%$ of that for Airy isostasy. The load of the pull-apart basin consists of the missing crust due to thinning and the load of the sediments that fill the hole. The deflection is calculated by a 2-D elastic plate model using a fast Fourier transform algorithm (J. C. Cochran, personal communication, 1985). The dimensions of the load of the Dead Sea basin are measured from Figure 7 and gridded at a 5 by $5 \mathrm{~km}$ intervals. The elastic thicknesses may be reduced by an unknown amount if the strike-slip faults bounding the basin do not support stresses.

The paradox can be resolved if, instead of subsidence with local Airy isostatic compensation, we assume subsidence without compensation

$$
S=H c(1-1 / \beta) .
$$

This formula represents constant volume for a 2-D extending crust with the Moho remaining fixed. A fixed (not elevated) Moho is indicated by the Bouguer profile across the basin (Figure 4). Moreover, the basin is probably close to being uncompensated (Figure 9), implying that the Moho under the basin is not significantly elevated. The basin will appear uncompensated for a lithosphere with an elastic thickness $>5 \mathrm{~km}$ because of the short wavelength of the load (Figure 9). The elastic thickness in the area is probably $>5 \mathrm{~km}$ because of the positive correlation between free air gravity and topography over wavelengths $>60 \mathrm{~km}$ (Plates 1 and 2 and Figure 3) and because of the normal heat flow in the area $\left(53 \mathrm{~mW} / \mathrm{m}^{2}\right.$ [Galanis et al., 1986]).

The amount of extension of an uncompensated Dead Sea basin is $21 \mathrm{~km}$ and $18 \mathrm{~km}$, respectively, for total subsidence of $4.7 \mathrm{~km}$ (132-km-long basin) and $7.57 \mathrm{~km}$ (71-km-long deep part). Dividing $21 \mathrm{~km}$ of extension by the relative plate motion of $6 \mathrm{~km} / \mathrm{m} . \mathrm{y}$., we find that the basin is $3.5 \mathrm{~m} . \mathrm{y}$. old, an age comparable to the age deduced from geological evidence [e.g., $\left.S a^{\prime} a r, 1985\right]$. The extension factors, $\beta=1.19$ and 1.34 , respectively, are much less than $\beta=1.5$, which was suggested to be the minimum value for decompression melting [McKenzie and Bickle, 1988]. There is, indeed, no evidence for upper mantle melting or asthenospheric upwelling under the basin.

\section{ConcLusions}

Analysis and modeling of gravity data reveal the geometry of the Dead Sea basin which is located within the Dead Sea transform valley. The basin is $132 \mathrm{~km}$ long, 7-18 $\mathrm{km}$ wide, and up to $10 \mathrm{~km}$ deep. The basin becomes narrower and shallower toward the northern and southern ends. There are 
no diagonal faults at the northern and southern ends of the basin; instead, the basin appears to sag toward the deepest part. The basin consists of $\sim 7$ - to $10-\mathrm{km}$-wide full graben and is flanked along much of its length by tilted blocks of medium depth. These blocks are interpreted to represent a passive collapse of parts of the wider transform valley into the deepening graben. The collapse may have been facilitated by the normal faults that bound the transform valley.

We propose that the basin was formed by crustal stretching along its long axis with maximum stretching concentrated in the center and with sagging of the northern and southern ends toward the center. Several lines of evidence indicate that deformation occurred wholly within the crust (both brittle and ductile) without the participation of the upper mantle. The stretching and sediment loading are probably not compensated isostatically implying that the Moho is not elevated under the basin.

The Dead Sea basin (and possibly other pull-apart basins) can be used to study crustal deformation resulting from a purely mechanical stretching because thermal input appears to be minimal.

Acknowledgments. Permission to publish the land data was generously granted via the efforts of $Y$. Rotstein and $\mathrm{K}$. Jreisat. We thank Amoco Oil Co. for supplying their gravity data. We thank G. Amit and A. Golan, National Institute of Limnology and Oceanography, Israel, for their help in obtaining and reducing the navigation data; M. Gonen, the owner and captain of the Tiulit for his help at sea; N. Schoenberg; and the Institute of Petroleum Research and Geophysics, Israel for measurements of the tie-in gravity station. L. North helped reduce the Jordanian gravity measurements, and J. Zwinakis drafted many of the figures. We thank D. Hutchinson, M. Steckler, and D. Forsyth for helpful discussions; W. Dillon, R. Oldale, and G. Shamir for their comments on the manuscript; and P. Morgan, Y. Rotstein, and an anonymous for their reviews. Data acquisition and part of the reduction were funded by a grant from the Basic Research Foundation of the Israel Academy of Science.

\section{REFERENCES}

Arbenz, J. K., Oil potential of the Dead Sea area, Rep 84/111, Seismica Oil Explor. Ltd., Tel Aviv, 1984.

Bell, R. E., and A. B. Watts, Evaluation of the BGM-3 sea gravity meter system on board R/V Conrad, Geophysics, 51, 1480-1493, 1986.

Ben-Avraham, Z., and M. D. Zoback, Transform-normal extension and asymmetric basins: An alternative to pull-apart models, Geology, 20, 423-426, 1992.

Bender, F., Geologie von Jordanien, 230 pp., Borntraeger, Berlin, 1968.

Bentor, Y. K., A. Vroman, and I. Zak, Geological map of Israel, scale 1:250,000, southern sheet, Govt. Printer, Jerusalem, 1965.

Bilham, R., and G. King, The morphology of strike-slip faults: Examples from the San Andreas fault, California, J. Geophys. Res., 94, 10,204-10,216, 1989.

Bott, M. H. P., A simple criterion for interpreting negative gravity anomalies, Geophys., 27, 376-381, 1962.

Byerlee, J. D., Friction of rocks, Pure Appl. Geophys., 116, 615-626, 1978.

Campbell, D. L., Basic programs to calculate gravity and magnetic anomalies for $21 / 2$ dimensional prismatic bodies, U.S. Geol. Surv. Open File Rep., 83-0154, 38 pp., 1983.

Christie-Blick, N., and K. T. Biddle, Deformation along strike-slip faults, in Deformation and Basin Formation Along Strike-Slip Faults, edited by K. T. Biddle and N. Christie-Blick, Spec. Publ. Soc. Econ. Paleontol. Mineral., 37, 1-34, 1985.

Crowell, J. C., Origin of late Cenozoic basins in southern California, in Tectonics and Sedimentation, edited by W. R. Dickinson, Spec. Publ. Soc. Econ. Paleontol. Mineral., 22, 190-204, 1974.

Eckstein, Y., and G. Simmons, Measurements and interpretation of terrestrial heat flow in Israel, Geothermics, 6, 117-142, 1978.
El-Isa, Z., J. Mechie, C. Prodehl, J. Makris, and R. Rihm, A crustal structure study of Jordan derived from seismic refraction data, Tectonophysics, 138, 235-253, 1987.

Folkman, Y., Magnetic and gravity investigations of the crustal structure in Israel, Ph.D. thesis, Tel Aviv Univ., Tel Aviv, 1976.

Fonofoff, N. P., and R. C. Millard, Jr., Algorithms for computation of fundamental properties of sea water, UNESCO Tech. Pap. Mar. Sci., 44, 53 pp., UNESCO, Paris, 1983.

Freund, R., and Z. Garfunkel, Guidebook to the Dead Sea rift, 27 pp., Hebrew University, Jerusalem, 1976.

Galanis, S. P., J. H. Sass, R. J. Munroe, and M. Abu-Ajamieh, Heat flow at Zarqa Main and Zara and a geothermal reconnaissance of Jordan, U.S. Geol. Surv. Open File Rep., 86-631, 110 pp., 1986.

Garfunkel, Z., Internal structure of the Dead Sea leaky transform (rift) in relation to plate kinematics, Tectonophysics, 80, 81-108, 1981

Ginzburg, A., and Y. Folkman, Geophysical investigation of crystalline basement between Dead Sea rift and Mediterranean Sea, AAPG Bull., 65, 490-500, 1981.

Hall, J. K., and D. Neev, The Dead Sea geophysical survey, Final report no. 1, Survey methods and data analysis, $\operatorname{Rep} . M G D 2 / 75$, 27 pp., Geol. Surv. of Isr., Jerusalem, 1975.

Ilani, S., The paleogeography of the Pleshet and Ahuzam Formations (Pliocene-Pleistocene) in the western Shomeron Foothills, Israel, J. Afr. Earth Sci., 11, 233-242, 1990.

Joffe, S., and Z. Garfunkel, Plate kinematics of the circum Red Sea-A reevaluation, Tectonophysics, 141, 5-23, 1987.

Kashai, E. L., A review of the relations between the tectonics, sedimentation and petroleum occurrences of the Dead Sea-Jordan Rift system, in Triassic-Jurassic Rifting: Continental Breakup and the Origin of the Atlantic Ocean and Passive Margins, edited by W. Manspeizer, Dev. Geotectonics, 22, 883-909, 1988.

Kashai, E. L., and P. F. Crocker, Structural geometry and evolution of the Dead Sea-Jordan rift system as deduced from new subsurface data, Tectonophysics, 141, 33-60, 1987.

Kusznir, N. J., and R. G. Park, The extensional strength of continental lithosphere: Its dependence on geothermal gradient, and crustal composition and thickness, in Continental Extensional Tectonics, edited by M. P. Coward, J. F. Dewey, and P. L. Hancock, Spec. Publ. Geol. Soc. Am., 28, 35-52, 1987.

Lachenbruch, A. H., J. H. Sass, R. J. Munroe, and T. H. Moses, Geothermal setting and simple heat conduction models for the Long Valley Caldera, J. Geophys. Res., 81, 769-784, 1976.

McKenzie, D. P., Some remarks on the development of sedimentary basins, Earth Planet. Sci. Lett., 40, 25-32, 1978.

McKenzie, D. P., and M. J. Bickle, The volume and composition of melt generated by extension of the lithosphere, J. Petrol., 29, 625-679, 1988 .

Morelli, C., The International Gravity Standardization Net 1971, Spec. Publ. 4, 120 pp., Int. Assoc. of Geod., Paris, 1971.

Neev, D., and J. K. Hall, The Dead Sea geophysical survey, Final report no. 2, Seismic results and interpretation, Rep. MGD 6/76, 21 pp., Geol. Surv. of Isr., Jerusalem, 1976.

Picard, L., and U. Golani, Geological map of Israel, scale 1:250,000, northern sheet, Govt. Printer, Jerusalem, 1965.

Quennell, A. M., Tectonics of the Dead Sea Rift, paper presented at 20th International Geological Congress, Assoc. of Serv. Geol. of Afr., Mexico City, Mexico, 1959.

Reches, Z., Mechanical aspects of pull-apart basins and push-up swell with applications to the Dead Sea transform, Tectonophysics, 141, 75-88, 1987.

Reches, Z., and D. F. Hoexter, Holocene seismic and tectonic activity in the Dead Sea area, Tectonophysics, 80, 235-254, 1981.

Rodgers, D. A., Analysis of pull-apart basin development produced by en echelon strike-slip faults, Spec. Publ. Int. Assoc. Sedimentol., 4, 27-41, 1980.

Rotstein, Y., Y. Bartov, and A. Hofstetter, Active compressional tectonics in the Jericho area, the Dead Sea rift, Tectonophysics, 198, 239-259, 1991.

Royden, L. H., The Vienna basin: A thin-skinned pull-apart basin, in Deformation and Basin Formation Along Strike-Slip Faults, edited by K. T. Biddle and N. Christie-Blick, Spec. Publ. Soc. Econ. Paleontol. Mineral., 37, 319-338, 1985.

$\mathrm{Sa}$ 'ar, H., Origin and sedimentation of sandstones in graben fil formations of the Dead Sea rift valley, Rep. $M M / 3 / 86$, Geol. Surv. of Isr., Jerusalem, 1985. 
Schubert, G., and Z. Garfunkel, Mantle upwelling in the Dead Sea and Salton Trough-Gulf of California leaky transforms, Ann. Geophys., 2, 633-648, 1984.

Segall, P., and D. D. Pollard, Mechanics of discontinuous faults, $J$. Geophys. Res., 85, 4337-4350, 1980.

Steckler, M. S., and U. S. ten Brink, Lithospheric strength variations as a control on new plate boundaries: Examples from the northern Red Sea region, Earth Planet. Sci. Lett., 79, 120-132, 1986.

ten Brink, U. S., and Z. Ben-Avraham, The anatomy of a pull-apart basin: seismic reflection observations of the Dead Sea basin, Tectonics, 8, 333-350, 1989.

ten Brink, U. S., N. Schoenberg, R. L. Kovach, and Z. BenAvraham, Uplift and a possible Moho offset across the Dead Sea Transform, Tectonophysics, 180, 77-92, 1990.

ten Brink, U. S., D. F. Coleman, L. North, R. Bell, M. Hassouneh, Z. Ben-Avraham, and G. Andreasen, Gravity maps of the Dead Sea Basin, 1:250,000, U.S. Geol. Surv. Geophys. Invest. Ser., in press, 1993.

Turcotte, D. L., and G. Schubert, Geodynamics, 450 pp., John Wiley, New York, 1982.

van Eck, T., and A. Hofstetter, Microearthquake activity in the Dead Sea region, Geophys. J. Int., 99, 605-620, 1989.
Wessel, P., and A. B. Watts, On the accuracy of marine gravity measurements, J. Geophys. Res., 93, 393-413, 1988.

Withjack, M. O., and W. R. Jamison, Deformation produced by oblique rifting, Tectonophysics, 126, 99-124, 1986.

Zak, I., The geology of Mt. Sedom (in Hebrew, English abstract), Ph.D. thesis, 208 pp., Hebrew Univ., Jerusalem, 1967.

Zak, I., and R. Freund, Asymmetry and basin migration in the Dead Sea Rift, Tectonophysics, 80, 27-38, 1981.

R. E. Bell and B. Coakley, Lamont-Doherty Earth Observatory, Palisades, NY 10964.

Z. Ben-Avraham and G. Tibor, Department of Geophysics and Planetary Sciences, Tel Aviv University, Tel Aviv 69978, Israel

D. F. Coleman and U. S. ten Brink, U.S. Geological Survey, Quinsett Campus, Woods Hole, MA 02543.

M. Hassouneh, Geology Division, Natural Resources Authority, Amman, Jordan.

(Received November 24, 1992; revised May 18, 1993; accepted July 21, 1993.) 